Research, part of a Special Feature on Canada and Transboundary Fisheries Management in Changing Oceans: Taking Stock. Future Scenarios

\title{
Climate change, shifting threat points, and the management of transboundary fish stocks
}

\author{
U. Rashid Sumaila $^{1,2}$, Juliano Palacios-Abrantes $^{3}$ and William W. L. Cheung $^{3}$
}

\begin{abstract}
We apply the concept of threat points in game theory to explore the stability of current joint management arrangements for shared transboundary fish stocks between Canada and the United States. We use three examples to explore the effects of projected impacts of climate change on the productivity and distribution of these stocks between the exclusive economic zones of the two countries. The three stocks that we study are: Atlantic cod (Gadus morhua) and yellowtail flounder (Limanda ferruginea) within the Gulf of Maine, and Pacific halibut (Hippoglossus stenolepis) in the Pacific Coast. We define a threat point as the payoffs that the fisheries in Canada and the United States take home given the current management agreement between the two countries. This is an application of John Nash's threat point, defined as the minimum payoffs that each player in a game theoretic model must receive for the solution to a cooperative game to be stable, which is usually the outcome of a noncooperative game. First, we compute the threat points, that is, the current profits that Canada and the United States derive from the three shared stocks, respectively. Next, we build an ensemble of climate-marine ecosystem and economic models and use them to determine how climate change is likely to change current profits received by each country relative to the shifts in their threat points. We find that in some cases the profits obtained by fisheries in Canada and the United States would change under climate change both in absolute and relative terms resulting in relative changes in threat points. These relative changes in threat points serve as the basis for our discussion of the stability of current transboundary management agreements between Canada and the United States for these important shared stocks in the face of climate change.
\end{abstract}

Key Words: Atlantic cod; climate change; joint management; Pacific halibut; shared stocks; yellowtail flounder

\section{INTRODUCTION}

Climate change is having an impact on marine biodiversity (Pörtner et al. 2014, Gattuso et al. 2015, Cheung et al. 2009) with marine species shifting their distributions (Cheung et al. 2013, Pinsky et al. 2013), and some fish stocks recording decreases in their productivities and potential fisheries catches (Free et al. 2019). Moreover, as climate change continues to develop, it is projected to have a substantial impact on the management and economics of fisheries worldwide if temperatures are not held below $1.5^{\circ} \mathrm{C}$ above preindustrial levels (Hoegh-Guldberg et al. 2018). Such impacts include reduction in the potential catch of exploited marine species (Noone et al. 2013, Gattuso et al. 2015), a decrease in potential fisheries revenues (Lam et al. 2016), on household budgets for seafood consumers (Sumaila 2019), and on social benefits they provide (Allison et al. 2009), as well as increased conflict between neighboring nations (Pinsky et al. 2018).

There are three types of shared fish stocks: (1) transboundary fish stocks are those that migrate between the exclusive economic zone (EEZ) of two or more neighboring coastal states; (2) straddling fish stocks that migrate between neighboring EEZs and the high seas; and (3) highly migratory (straddling) stocks, i.e., those stocks that migrate between the EEZ of one or more coastal states and the high seas, which in effect refers to tuna (Sumaila 2013). Game theoretic models have been applied by fishery economists to study the likely outcomes for the players in the game, as well as Nature in terms of the fate of the fish (Munro 1979, Sumaila 2013). This is because the theory is appropriate when more than one strategic player, e.g., Canada and the United States, fishes the same transboundary fish stock, e.g., Pacific halibut (Sumaila 1997a,
Bailey et al. 2010). Within game theory, John Nash's "threat point" is defined as the minimum payoffs that each player in a game theoretic model must receive for the solution to a cooperative game to be stable, which is usually the outcome of a noncooperative game (Nash 1953, Sumaila 2013). Game theoretic models have been employed to understand how to achieve economically efficient and stable outcomes as well as biologically sustainable fishery management (Clark 1980, Levhari and Mirman 1980). In particular, game theory has been employed to study the optimal management of transboundary fish stocks (Sumaila 1995, 1997b, 1997c, Armstrong 1999) and shared fisheries such as those for Barents sea cod (Sumaila 1997b), Pacific salmon (Miller and Munro 2002), Benguela Current hake (Sumaila et al. 2004), and Pacific sardine (Cisneros-Montemayor et al. 2020). Modeling studies and analysis of actual agreements also shed light on the conditions under which mutually beneficial cooperative management arrangements can be negotiated and maintained. Game theoretic models can play a useful role in explaining fisheries problems and assessing policy options. We use the concept of threat points to study how a game-theoretic perspective can contribute to understanding the challenges that climate change will present for internationally shared stocks, and how that understanding could be used to promote sustainable management of these resources.

We designate the current payoff to Canada and the United States under existing cooperative management arrangements for three transboundary stocks studied as the initial threat points for each country. Threat points are indicators of a player's bargaining power because it is the payoff that a player takes home in the event of a breakdown in cooperation.

${ }^{1}$ Fisheries Economics Research Unit, Institute for the Oceans and Fisheries, University of British Columbia, ${ }^{2}$ School of Public Policy and Global Affairs, University of British Columbia, Vancouver, British Columbia, Canada, ${ }^{3}$ Changing Ocean Research Unit, Institute for the Oceans and Fisheries, University of British Columbia, Vancouver, Canada 
Building on the model described in Palacios-Abrantes et al. (2020), we explore the economics of changing stock-share ratios between Canada and the United States. In particular, we calculate the current payoff or threat points of the two countries and determine how these are likely to shift relative to the status quo management regimes used to jointly manage the stocks under different scenarios of climate change. We then discuss how these projected changes are likely to affect the stability of current transboundary management arrangements for these species between the two neighboring countries.

Our results suggest that the instability of current management arrangements for the three transboundary fish stocks depends on the stock and the intensity of climate change. This finding implies that the current joint management regimes for two of the three stock studied (Atlantic cod Gadus morhua and yellowtail flounder Limanda ferruginea) would become less stable as climate change intensifies, making their management more challenging under intensifying global warming. For these stocks, the United States and Canada need to develop pre-emptive and flexible management and policy regimes that would make it possible to adjust existing joint management agreements periodically. For example, they could include in the agreement a periodic review of threat points that could then serve as a basis for renegotiation of existing agreements.

\section{METHODS}

We focus on three examples of transboundary fisheries jointly managed by Canada and the United States on both the Atlantic and the Pacific coasts. In the Atlantic Ocean, we focused on the Atlantic cod and yellowtail flounder stocks distributed within the Gulf of Maine in which Canada and the United States have an arrangement for managing these stocks (TRAC 2016, CIA 2017). In accordance, analyses of subsets of the total area were carried out for the Gulf of Maine arrangement according to the Northwest Atlantic Fisheries Organization's (NAFO) divisions $5 \mathrm{Y}, 5 \mathrm{Ze}$, and $4 \mathrm{X}$ within latitudes $46.2^{\circ} \mathrm{N}$ and $41.5^{\circ} \mathrm{S}$, and longitudes $-72^{\circ} \mathrm{W}$ and $-64^{\circ} \mathrm{E}$, respectively (Fig. 1). For the Pacific coast, the analysis was based on Pacific halibut (Hippoglossus stenolepis), managed by the International Pacific Halibut Commission (IPHC), which ranges from California (United States) to the waters off British Columbia (Canada) and Alaska (United States). Although fisheries negotiation[s] in the United States are operated by states, in this study Alaska and the United States contiguous states are considered as one player. Even though this assumption seems somewhat unrealistic, it is still useful because ultimately the United States decides as a country. In Canada, marine fisheries are managed by the federal government, and therefore the federal government of Canada is the sole player representing the country in this game.

We built an ensemble of climate-marine ecosystem and economic models (Lam et al. 2016, Sumaila 2019) and used them to determine how climate change is likely to change the current profits received by each country. We estimated changes to the biomass and maximum catch potential (MCP) of fish species under two contrasting climate-change scenarios characterized by the IPCC representative concentration pathways (RCP). The $\mathrm{RCP} 2.6$ is a strong mitigation greenhouse gas emissions scenario, which by the end of the twenty-first century is projected to lead to a net radiative forcing of $2.6 \mathrm{Wm}^{-2}$ (Meinshausen et al. 2011).
The RCP8.5 is a high greenhouse gas emissions scenario that projects a net radiative forcing of $8.5 \mathrm{Wm}^{-2}$ by the end of this century. Following the method described in Sumaila et al. (2019), MCP was projected using a dynamic bioclimatic envelope model (DBEM; Cheung et al. 2016) and an ensemble of earth system models (ESMs) consisting of the GFDL-ESM2M model from the U.S. National Oceanic and Atmospheric Administration's Geophysical Fluid Dynamics Laboratory (https://www.gfdl. noaa.gov/earth-system-model/), the IPSL-CM5LR model from the Institute Pierre Simon Laplace (https://cmc.ipsl.fr/ipslclimate-models/), and the MPI-ESM from the Max Planck Institute for Meteorology (https://www.mpimet.mpg.de/en/ science/models/mpi-esm/).

Fig. 1. Study area. The International Pacific Halibut Commission (IPHC) management area is in red and the Northwest Atlantic Fisheries Organization (NAFO) areas within the Gulf of Maine are represented in green.

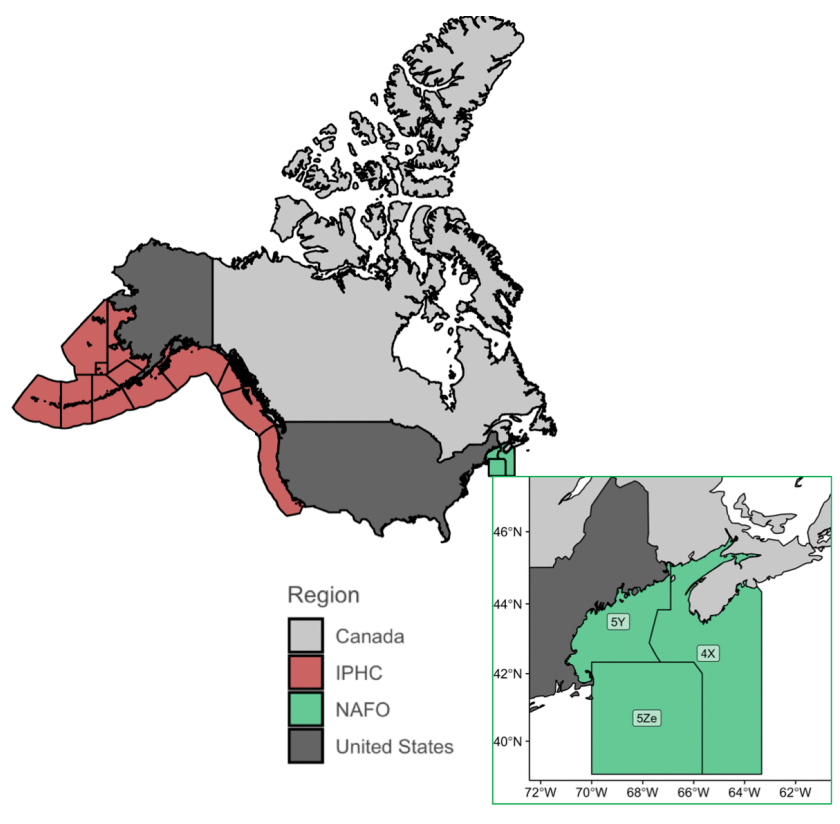

The ESMs simulate changes in temperature, oxygen content (represented by $\mathrm{O}_{2}$ concentration), net primary production, as well as other variables such as ocean current patterns, salinity, and sea-ice extent from 1951 to 2099. The outputs of the ESMs were then used to project the impacts of climate change on growth, production, and distribution of the three species under study (Cheung et al. 2010). To project future changes in biomass (B) and MCP of the three studied species, fishing mortality is assumed to be the level required to achieve maximum sustainable yield (see Cheung et al. 2016 for details of the method). Change in B and MCP of each species within the boundary of each player were estimated for each ESM under high emission and low emission scenarios from 2015 to 2099 relative to the current (2005 to 2014) period.

Based on the projected changes in MCP, we calculated changes in catches, total costs, and profits generated from the three fish stocks by Canada and the United States under the two climate 
scenarios. First, we calculated the current (from 2005 to 2014) annual catches, total cost, revenues, and profits under existing joint management arrangements between Canada and the United States. For each fishery, total cost was estimated as weighted average of gear costs and their respective catch share. Specifically, let $C_{p, t 0}$ denote the catch of player $p$ in the starting year (i.e., $\mathrm{t}=$ t0) and $V_{p, t 0}$ and $W_{p, t 0}$ represent the unit price and the unit cost of fishing by weight, respectively, then the profit to player $p$ at the start of the analysis, $\pi_{p, t 0}$, is given by:

$$
\begin{gathered}
\pi_{p, t 0}=\left(V_{p, t 0}-W_{p, t 0}\right) C_{p, t 0} \\
\mathrm{p}=[\text { Canada, United States }]
\end{gathered}
$$

Our key hypothesis is that climate change will change the relative profits to Canadian and American fisheries targeting Atlantic cod, Pacific halibut, and yellowtail flounder as it leads to changes in fish biomass productivity and distributions (Cheung et al. 2010, 2015). That is, $\pi_{p, t 0} \neq \pi_{p, t i}$ for each stock at $i=$ [midcentury, endof-midcentury]

We compute the potential shifts in threat points, for Canada and the United States, that is, the current value profits that the two countries are likely to generate under the two climate-change scenarios described at the mid- and end of the twenty-first century, respectively. Estimates were carried out for each ESM and presented as averages ( \pm s.d.) to account for model structural uncertainty. The relative changes in threat points serve as the basis for the discussion of the stability of current transboundary management agreements between Canada and the United States for these important shared stocks in the face of climate change (see NOAA 2018 for a list of bilateral agreements and arrangements). We compute present values of profits because for our purposes in this contribution, we are interested only in the relative, not absolute, profits under each scenario. The stability of existing transboundary management of the fish stocks is determined by the change in the proportion of the total profits generated from each stock by each country under high and low emission at midcentury (2041-2060) and end-of-century (2080-2099) relative to at the start of the analysis.

We implicitly assume that the share of the stock is dictated partly by its distribution across national maritime boundaries, and there is evidence of this with respect to Pacific salmon, where quotas had to be renegotiated in the past to adjust for changes in the distribution of this species between Canada and the United States (Miller and Munro 2002).

\section{Data}

We used reported landings (i.e., excluding discards) from the industrial fishing sector by fishing country, fishing gear (i.e., hook and line or trawl), and stock. Data for Atlantic cod and yellowtail flounder were provided by the Sea Around Us (Zeller et al. 2016). For Pacific halibut, landings data were provided by the IPHC. Natural history data for each species were gathered from FishBase. We relied on two main fisheries economics databases to estimate revenues. Ex-vessel price for each species caught by each country was obtained from Tai et al. (2017), which built on Sumaila et al. (2007) and Swartz et al. (2013). Fishing costs per fishing gear are needed to compute profits, which were obtained from Lam et al. (2011). It should be noted that we assume constant real prices. Partly, this allows us to isolate the effects of climate change. Still, it is possible to easily explore the effects of this assumption on our results by conducting sensitivity analysis on this parameter. We run a sensitivity analysis on the fixed costs and prices assumption considering three future scenarios in which these could change. For each scenario, we randomly selected three values from $5 \%$ to $50 \%$ using the $\mathrm{R}$ function runif ( $\mathrm{R}$ studio base) for both price and cost (Appendix 1, Table A1). We then estimated future cost and price (Var) for each future scenario $(l)$ for each species and country as f ${ }^{1}$ lows:

$$
\operatorname{Var}_{\mathrm{s}}=\mathrm{Or} * r
$$

Where $O r$ is the original value, $s$ is scenario, and $r$ is the random number. Finally, for each scenario, species, and EEZ, we estimated the future profit at midcentury under a high emission climatechange scenario (Appendix 1, Fig. A1).

\section{Addressing uncertainty}

Given the design of our analysis, we applied methods to capture the uncertainty embedded in the earth system models, climatechange scenarios, and the consequent modeling of species distributions under climate change (Palacios-Abrantes et al. 2020). The use of multiple ESMs allowed us to capture the structural uncertainty embedded in the climate-change models. Moreover, there is a natural ambiguity in future societal decisions regarding policies that address climate change. We addressed this uncertainty by considering two extreme RCP scenarios that encompass the whole spectrum of possible mitigation paths currently used by the IPCC. Perhaps more important for this study is the uncertainty surrounding the data providing key biological and economic parameters used to model species distributions and estimate the economic impact of such changes. All data used were collected from global efforts to construct fisheries-related databases applying different methods to address data gaps, thus, although these databases have been wildly used, they are not free from uncertainty (Lam et al. 2011, Zeller et al. 2016, Tai et al. 2017).

\section{RESULTS}

\section{Current profits generated by fisheries in Canada and the United States}

Current catches of Atlantic cod are somewhat balanced between Canada and the United States with a slight inclination toward Canada (Table 1). For yellowtail flounder, Canada's catches are almost double those of the United States. On the other hand, the United States takes about five times the catch compared to Canada when it comes to Pacific halibut. Although current discounted profits accruing to the countries follow the same patterns as in the case of catch for both yellowtail flounder and Pacific halibut, different ex-vessel prices per gear invert the pattern for Atlantic cod. According to the data, the United States' profit per tonne (US\$1803) is almost double that of Canada (US\$921); this is mainly due to the difference in ex-vessel price, which is almost US\$1000 per tonne higher in the United States.

The climate change projections suggest that by the midtwentyfirst century, both countries will see an increase in nondiscounted profits for Pacific halibut but a decrease for the other two species, regardless of the RCP scenarios (Fig. 2). Such a trend is expected to carry until the end of the twenty-first century, when both Canadian and American fisheries are expected to be less profitable, except in the case of Pacific halibut fisheries. 
Table 1. Current average (2005 to 2014) catch (million tonnes), total cost, revenue, and discounted (at 5\%) profit (million US\$ 2010) by species and country.

\begin{tabular}{|c|c|c|c|c|c|}
\hline \multirow[b]{2}{*}{ Species } & \multirow[b]{2}{*}{ Country } & \multirow{2}{*}{$\begin{array}{c}\text { Average } \\
\text { Catch }\end{array}$} & \multicolumn{3}{|c|}{ Total $^{\dagger}$ (million US\$) } \\
\hline & & & Cost & Revenue & Profit \\
\hline Atlantic cod & Canada & 1.42 & 2.41 & 3.72 & 1.07 \\
\hline (Gadus morhua) & United States & 1.17 & 2.08 & 4.13 & 1.67 \\
\hline Pacific halibut & Canada & 3.58 & 11.98 & 27.53 & 12.60 \\
\hline (Hippoglossus stenolepis) & United States & 18.13 & 60.68 & 132.09 & 57.83 \\
\hline Yellowtail flounder & Canada & 1.31 & 2.22 & 4.81 & 2.11 \\
\hline (Limanda ferruginea) & United States & 0.81 & 1.52 & 2.71 & 0.97 \\
\hline \multicolumn{6}{|c|}{$\begin{array}{l}\text { Prices of Atlantic cod for Canada and the United States per tonne are } \\
\text { US\$2618 and US\$3500, respectively; for Pacific halibut US\$7690 and } \\
\text { US\$7285, and for yellowtail flounder US\$3675 and US\$3343, } \\
\text { respectively. The average cost of all fishing gears for Atlantic cod in } \\
\text { Canada and the United States per tonne is US\$1697 (960) and US\$2003, } \\
\text { respectively; for Pacific halibut, US\$3346 for both countries, and for } \\
\text { yellowtail flounder US\$1700 (960) and US\$2003, respectively. }\end{array}$} \\
\hline
\end{tabular}

Fig. 2. Average ( \pm standard deviation) profits generated by fisheries in Canada and the United States under climate change. Midcentury represents the average of 2041-2060, and end-ofcentury is the average of 2080-2099. Values presented in constant US\$2010 million. Solid line represents profits discounted to $5 \%$ and shaded dotted line represents nondiscounted profits.
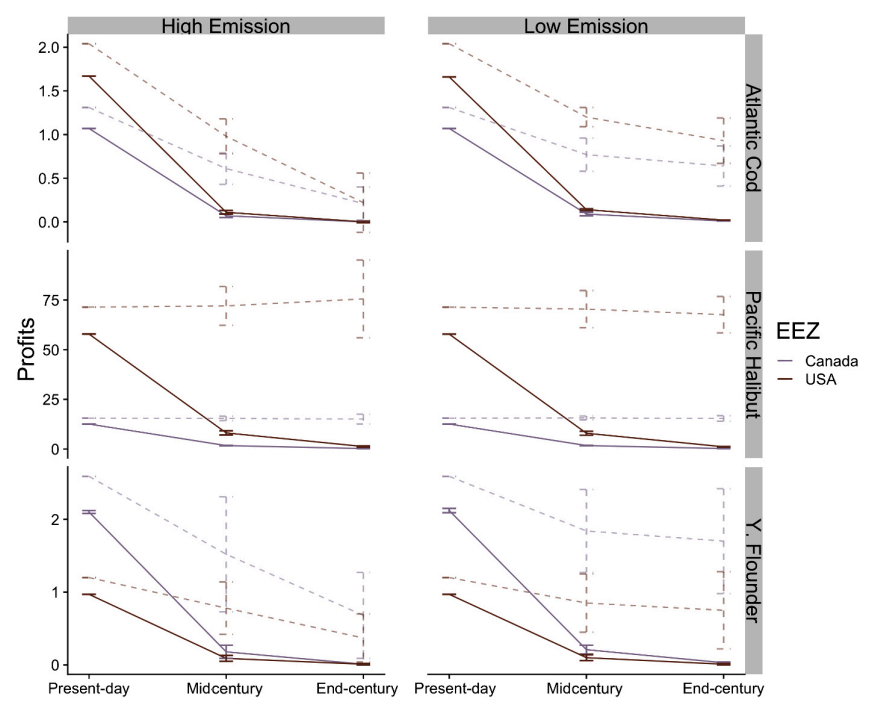

Proportion of total profits, threat point shifts, and the stability of current joint management arrangements

The average share of profit to the two countries changes for both Atlantic cod and yellowtail flounder under high emissions whereas in the case of halibut the share or proportions of profits is very stable regardless of the climate change scenario (Fig. 3). For Atlantic cod, the relative threat point payoffs to Canada as climate change intensifies shows the country's share of profit increasing from a low of $39 \%$ initially to a high of $65 \%$ of total profit under high emissions. This is mainly due to a potential poleward shift in the species distribution, therefore, increasing catch on Canada's EEZ. Although less certain, a shift is possible even under a low emissions scenario. Finally, yellowtail flounder's average proportion shows a decrease in Canada's bargaining power toward midcentury under high emission. The pattern then inverts by the end of the century, with an actual increase in the bargaining power of Canada to even higher than initially. However, uncertainty from ESMs leaves the possibility of a potential shift by the end of the century under a high-emission scenario, or important reduction to almost 50-50 in the proportion of total profit under a low-emission scenario.

Fig. 3. Proportion of total profits by country (Canada purple, United States maroon), species, and climate scenario (left panel high emission, right panel low emission). Solid line represents average earth system models (ESM). Error bars represent average $\pm 2 *$ s.d.
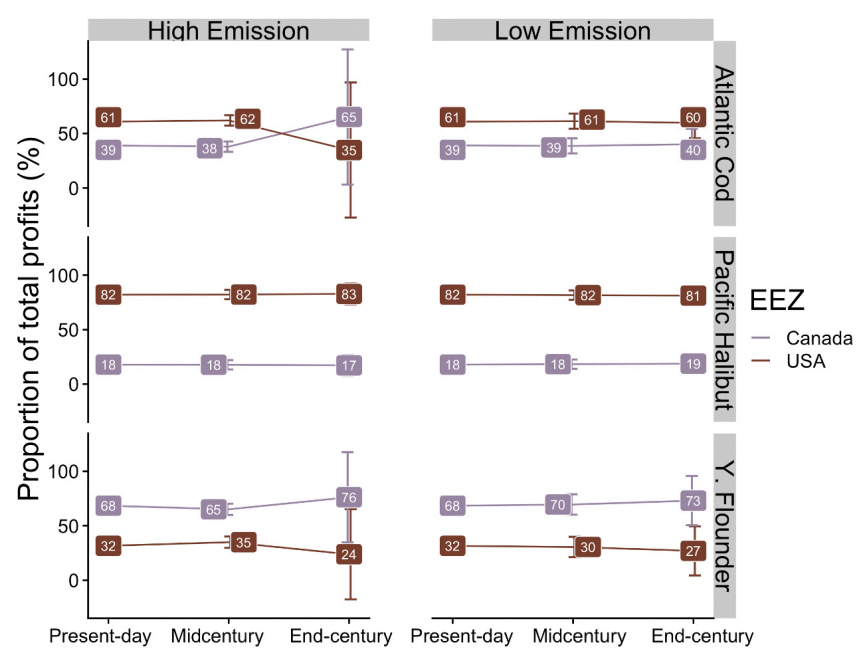

\section{DISCUSSION AND CONCLUSION}

We focused on how climate change is likely to affect the stability and resilience of current management arrangements for transboundary fish stocks, which are shared between Canada and the United States. We applied a game theory model for two players (Canada, United States) to examine how the threat points of three important transboundary fisheries would likely shift as climate change intensifies. In a broad sense, we addressed the question of how climate change might affect the economic prospects for the cooperative governance of fisheries that are shared between nations in these examples.

As shown in Table 1, there is a large difference between profits generated by Pacific halibut between Canada and the United States. This is because the United States regions are allocated $80 \%$ of the total allowable catch (TAC) of Pacific halibut because Canada has only one region (2B off the coast of British Columbia; IPHC 2019). Our analysis suggests that the current joint management arrangement between Canada and the United States for Pacific halibut is likely to be stable and resilient to changes in climate, at least to some extent (Fig. 1). The initial joint 
management equilibrium payoffs turned out to be very stable with the initial proportion of total profit to the two countries virtually unchanged under both scenarios of climate change. This is most likely because of the movement of halibut to Canada from the contiguous United States and a subsequent movement from Canada to Alaska. In addition, there is a potential upward expansion of the fishery's range due to a more suitable environment (Palacios-Abrantes et al. 2020). Thus, the potential increase in Alaska's landings is larger than the loss in the contiguous states. This is, however, not the case for current transboundary management of Atlantic cod and yellowtail flounder in the Gulf of Maine. Despite an overall reduction in profits within the region, the average proportion for Atlantic cod under high emissions will change in favor of Canada, thus increasing the bargaining power of that country vis-à-vis the United States. This is because threat points will practically switch from an initial domination of United States (61\% vs 39\% of Canada) to a Canadian majority by the end of the century of $65 \%$ to $35 \%$ of the United States. The implication is that the current joint management arrangements for this stock are unstable and not resilient to the impacts of climate change on the distribution and productivity of these stocks.

In the case of yellowtail flounder, Canada not only harvests more of the stock within the study area, but also has a lower cost of fishing, a factor of the gears used and the ex-vessel price. The fluctuation in the proportion of the yellowtail flounder stock as the species' habitat expands to new suitable grounds represents a challenge for joint fisheries management. For example, within the agreement, the management of cod and yellow flounder are limited to eastern subpopulations within the Gulf of Maine, thus potential localized changes in the stock distribution could be of even more significant importance to the arrangement's resilience (Palacios-Abrantes 2020). Such fluctuation also represents instability and a threat to the treaty longevity as happened in the late 1970s when Canada and the United States broke off negotiations over Pacific salmon. An environmental driven shift in the Fraser River sockeye salmon (Oncorhynchus nerka) stock resulted in large interceptions by the Canadian fleet driving the United States fleet to an increase in salmon capture. This new situation created an imbalance in the Pacific Salmon Treaty, threatening the sustainability of the stock. The negotiations lasted for 10 years and joint management was only reinstated after a series of modifications in the treaty including creation of a conservation fund that works as a de facto side payment (Miller et al. 2013).

Cooperation over transboundary stocks can have different levels of agreement, from scientific cooperation to full joint management (Miller et al. 2013) and players from two (e.g., Canada and the United States over Pacific halibut ) to multiple (e.g., regional fisheries management organizations that oversee tuna-like species are composed of multiple nations). For example, Canada, Mexico, and the United States share Pacific sardine (Sardinops sagax) in the California Current. However, although Mexico and the United States have a memorandum of understanding for scientific collaboration over marine resources in the Pacific (MEXUS-Pacifico research program; NOAA 2018), Canada and the United States lack any formal agreement that includes sardine (DFO 2018). It has been demonstrated that ecosystem-based cooperative fishing strategies outperform partial and noncooperative strategies when the economic benefits from the Pacific sardine fishery are considered as a whole, rather than country specific (Cisneros-Montemayor et al. 2020). Moving toward a joint cooperation scheme for this species is especially important as sardine distribution is strongly influenced by climate and thus hard to anticipate as climate historic patterns changes in the region (Bond et al. 2015, Cavole et al. 2016, CisnerosMontemayor et al. 2020). Unlike the IPHC in which rules emplaced are to be followed by parties, the Gulf of Maine arrangement is not official (e.g., allocation rules are suggested not binding) making it less resilient to future stock shifts (PalaciosAbrantes et al. 2020). For example, despite a weighted quota allocation of the Gulf of Maine stocks' distribution (90-10\% current and historical distribution, respectively; TRAC 2016), countries do not have any obligation to the proposed quota and the ultimate decision is made at the country level (Soboil and Sutinen 2006). Formalizing these types of arrangements will strengthen their legal basis making them more resilient to the impacts of climate change, such as those presented (Miller et al. 2013).

There are ecological and social-political gaps that cooperative transboundary fishing agreements and arrangements will have to address to prepare for climate change. Overall, countries will need to be ready to share more information and collaborate on scientific advances to tackle the ecological uncertainties embedded in climate change (Miller et al. 2013). It will be fundamental for international agreements as well as arrangements to explicitly address climate change within their management measures (see Koubrak and VanderZwaag 2020). This will not only generate paths for response (rather than wait and act) but will also reduce the velocity mismatch between species distributional change and that of policy implementation (Pinsky and Fogarty 2012). Specifically, management tools will need to be included as species shift their distribution reaching new EZZs (Pinsky et al. 2018) and exiting others (Oremus et al. 2020). Finally, collaborative policy frameworks will have to be adaptive, inclusive, flexible, and ecosystem-based if agreements are to resist the uncertainties related to climate change (Engler 2020, PalaciosAbrantes et al. 2020).

As previously mentioned, accounting for the impact of uncertainty on fisheries management under climate change is important to adopt the best management decisions looking forward (Morley et al. 2018). We captured two main sources of uncertainty in our analysis, that of the different ESMs' structure (error bars in Figure 1) and that of the climate-change scenarios to follow. Pacific halibut shows the less variation in terms of both structural and scenario uncertainty. This could be due to a better resolution of the ESMs at larger spatial scales (Morley et al. 2018) as well as the DBEM at the management area level. Currently, the IPHC regulatory areas cover most of the species' known distribution (IPHC and Gustafson 2017; see also http://www. aquamaps.org). Therefore, a potential poleward shift in the stock would most likely affect the southern regions (Canada and the United States below latitude 43) as seen in Palacios-Abrantes et al. (2020). Although this shift could have other types of complications, it might not be an issue when thinking about threat points and joint management at the federal level. The implications are different for both Atlantic cod and yellowtail flounder. The possibility of shifting threat points, even under a low emission 
scenario, creates a challenge for managing these shared stocks. Planning ahead for this type of fluctuation in stock proportion and applying more local-based models could reduce the uncertainty and increase the resilience of the agreements and help the sustainability of the fisheries.

Responses to this article can be read online at: https://www.ecologyandsociety.org/issues/responses. php/11660

\section{Acknowledgments:}

This is a product of the OceanCanada Partnership funded by the Social Sciences and Humanities Research Council of Canada. The authors thank Ms. Susan Rolston for her support in the production of the manuscript and the two anonymous reviewers for their insightful and useful comments.

\section{Data Availability:}

The data generated by this study can be accessed through https:// oceancanada.org/data-tools/ and code used for the analysis can be found at https://github.com/jepa/OC_Transboundary.

\section{LITERATURE CITED}

Allison, E. H., A. L. Perry, M. C. Badjeck, W. N. Adger, K. Brown, D. Conway, A. S. Halls, G. M. Pilling, J. D. Reynolds, N. L. Andrew, and N. K. Dulvy. 2009. Vulnerability of national economies to the impacts of climate change on fisheries. Fish and Fisheries 10(2):173-196. https://doi.org/10.1111/j.1467-2979.2008.00310. $\underline{\mathrm{X}}$

Armstrong, C. W. 1999. Sharing a fish resource - bioeconomic analysis of an applied allocation rule. Environmental and Resource Economics 13(1):75-94.

Bailey, M., U. R. Sumaila, and M. Lindroos. 2010. Application of game theory to fisheries over three decades. Fisheries Research 102(1-2):1-8. https://doi.org/10.1016/j.fishres.2009.11.003

Bond, N. A., M. F. Cronin, H. Freeland, and N. Mantua. 2015. Causes and impacts of the 2014 warm anomaly in the NE Pacific. Geophysical Research Letters 42:3414-3420. https://doi. org/10.1002/2015GL063306

Cavole, L. M., A. M. Demko, R. E. Diner, A. Giddings, I. Koester, C. M. L. S. Pagniello, M.-L. Paulsen, A. Ramírez-Valdez, S. M. Schwenck, N. K. Yen, M. E. Zill, and P. J. S. Franks. 2016. Biological impacts of the 2013-2015 warm-water anomaly in the Northeast Pacific: winners, losers, and the future. Oceanography 29(2):273-285. https://doi.org/10.5670/oceanog.2016.32

Central Intelligence Agency (CIA). 2017. The US-Canadian dispute over the Georges Bank. Central Intelligence Agency, Washington, D.C., USA. [online] URL: https://www.cia.gov/ library/readingroom/docs/CIA-RDP08C01297R000800220001-1. pdf

Cheung, W. W. L., R. D. Brodeur, T. A. Okey, and D. Pauly. 2015. Projecting future changes in distributions of pelagic fish species of Northeast Pacific shelf seas. Progress in Oceanography 130 (C):19-31. https://doi.org/10.1016/j.pocean.2014.09.003

Cheung, W. W. L., M. C. Jones, G. Reygondeau, C. A. Stock, V. W. Y. Lam, and T. L. Frölicher. 2016a. Structural uncertainty in projecting global fisheries catches under climate change. Ecological Modelling 325:57-66. https://doi.org/10.1016/j. ecolmodel.2015.12.018

Cheung, W. W. L., V. W. Y. Lam, J. L. Sarmiento, K. Kearney, R. Watson, and D. Pauly. 2009. Projecting global marine biodiversity impacts under climate change scenarios. Fish and Fisheries 10 (3):235-251. https://doi.org/10.1111/j.1467-2979.2008.00315.x

Cheung, W. W. L., V. W. Lam, J. L. Sarmiento, K. Kearney, R. Watson, D. Zeller, and D. Pauly. 2010. Large-scale redistribution of maximum fisheries catch potential in the global ocean under climate change. Global Change Biology 16:24-35. https://doi. org/10.1111/j.1365-2486.2009.01995.x

Cheung, W. W. L., R. Watson, and D. Pauly. 2013. Signature of ocean warming in global fisheries catch. Nature 497 (7449):365-369. https://doi.org/10.1038/nature12156

Cisneros-Montemayor, A. M., G. Ishimura, G. R. Munro, and U. R. Sumaila. 2020. Ecosystem-based management can contribute to cooperation in transboundary fisheries: the case of pacific sardine. Fisheries Research 221:105401. https://doi.org/10.1016/j. fishres.2019.105401

Clark, C. W. 1980. Restricted access to common-property fishery resources: a game-theoretic analysis. Pages 117-132 in P.-T. Liu, editor. Dynamic optimization and mathematical economics. Springer, Boston, Massachusetts, USA. https://doi. org/10.1007/978-1-4684-3572-6_7

Department of Fisheries and Oceans (DFO). 2018. Integrated fisheries management plan summary. Pacific sardine (Sardinops sagax), Pacific region, 2018-2021. Department of Fisheries and Oceans, Ottawa, Ontario, Canada. [online] URL: https://www. pac.dfo-mpo.gc.ca/fm-gp/mplans/sardine-ifmp-pgip-sm-eng.html

Engler, C. 2020. Transboundary fisheries, climate change, and the ecosystem approach: taking stock of the international law and policy seascape. Ecology and Society 25(4):43. https://doi. org/10.5751/ES-11988-250443"

Free, C. M., J. T. Thorson, M. L. Pinsky, K. L. Oken, J. Wiedenmann, and O. P. Jensen. 2019. Impacts of historical warming on marine fisheries production. Science 363 (6430):979-983. https://doi.org/10.1126/science.aau1758

Gattuso, J. P., A. Magnan, R. Billé, W. W. L. Cheung, E. L. Howes, F. Joos, D. Allemand, L. Bopp, S. R. Cooley, C. M. Eakin, O. Hoegh-Guldberg, R. P. Kelly, H. O. Pörtner, A. D. Rogers, J. M. Baxter, D. Laffoley, D. Osborn, A. Rankovic, J. Rochette, U. R. Sumaila, S. Treyer, and C. Turley. 2015. Contrasting futures for ocean and society from different anthropogenic $\mathrm{CO} 2$ emissions scenarios. Science 349(6243):aac4722. https://doi.org/10.1126/ science.aac4722

Hoegh-Guldberg, O., D. Jacob, M. Taylor, M. Bindi, S. Brown, I. Camilloni, R. Diedhiou, K. L. Djalante Ebi, F. Engelbrecht, J. Guiot, Y. Hijioka, S. Mehrotra, A. Payne, S. I. Seneviratne, A. Thomas, R. Warren, and G. Zhou. 2018. Impacts of $1.5^{\circ} \mathrm{C}$ global 
warming on natural and human systems. In V. Masson-Delmotte, P. Zhai, H. O. Pörtner, D. Roberts, J. Skea, P. R. Shukla, A. Pirani, W. Moufouma-Okia, C. Péan, R. Pidcock, S. Connors, J. B. R. Matthews, Y. Chen, X. Zhou, M. I. Gomis, E. Lonnoy, T. Maycock, M. Tignor, and T. Waterfield, editors. Global warming of $1.5^{\circ} \mathrm{C}$ an IPCC special report on the impacts of global warming of $1.5^{\circ} \mathrm{C}$ above pre-industrial levels and related global greenhouse gas emission pathways in the context of strengthening the global response to the threat of climate change, sustainable development, and efforts to eradicate poverty. Intergovernmental Panel on Climate Change, Geneva, Switzerland. [online] URL: https:// www.ipcc.ch/site/assets/uploads/sites/2/2019/02/SR15 Chapter3_Low_Res. pdf

International Pacific Halibut Commission (IPHC). 2019. International Pacific Halibut Commission, Pacific halibut fishery regulations. IPHC, Seattle, Washington, USA. [online] URL: https://www.iphc.int/uploads/pdf/regs/iphc-2019-regs.pdf

International Pacific Halibut Commission (IPHC), and $\mathrm{K}$. Gustafson. 2017. IPHC annual report 2016. IPHC, Seattle, Washington, USA. [online] URL: https://iphc.int/uploads/pdf/ ar/IPHC-2016-Annual-Report.pdf

Koubrak, O., and D. L. VanderZwaag. 2020. Are transboundary fisheries management arrangements in the Northwest Atlantic and North Pacific seaworthy in a changing ocean? Ecology and Society 25(4):42. https://doi.org/10.5751/ES-11835-250442

Lam, V. W. Y., W. W. L. Cheung, G. Reygondeau, and U. R. Sumaila. 2016. Projected change in global fisheries revenues under climate change. Scientific Reports 6(1):1-8. https://doi. org/10.1038/srep32607

Lam, V. W., U. R. Sumaila, A. Dyck, D. Pauly, and R.- Watson. 2011. Construction and first applications of a global cost of fishing database. ICES Journal of Marine Science 68 (9):1996-2004. https://doi.org/10.1093/icesjms/fsr121

Levhari, D., and L. J. Mirman. 1980. The great fish war: an example using a dynamic Cournot-Nash solution. Bell Journal of Economics 11(1):322-334.

Meinshausen, M., S. J. Smith, K. Calvin, J. S. Daniel, M. L. T. Kainuma, J.-F. Lamarque, K. Matsumoto, S. A. Montzka, S. C. B. Raper, K. Riahi, A. Thomson, G. J. M. Velders, and D. P. P. van Vuuren. 2011. The RCP greenhouse gas concentrations and their extensions from 1765 to 2300. Climatic Change 109 (1-2):213-241. https://doi.org/10.1007/s10584-011-0156-Z

Miller, K. A., and G. Munro. 2002. Cooperation and conflicts in the management of transboundary fishery resources. Proceedings of the second world conference of the American and European Associations of Environmental and Resource Economics. University of California San Diego, La Jolla, California, USA. [online] URL: https://econweb.ucsd.edu/ carsonvs/papers/440. pdf

Miller, K. A., G. R. Munro, U. R. Sumaila, and W. W. L. Cheung. 2013. Governing marine fisheries in a changing climate: a gametheoretic perspective. Canadian Journal of Agricultural Economics/Revue canadienne d'agroeconomie 61(2):309-334. https://doi.org/10.1111/cjag.12011
Morley, J. W., R. L. Selden, R. J. Latour, T. L. Frölicher, R. J. Seagraves, and M. L. Pinsky. 2018. Projecting shifts in thermal habitat for 686 species on the North American continental shelf. PLoS ONE 13(5):e0196127. https://doi.org/10.1371/journal. pone. 0196127

Munro, G. R. 1979. The optimal management of transboundary renewable resources. Canadian Journal of Economics 12 (3):355-376.

Nash, J. 1953. Two-person cooperative games. Econometrica 21 (1):128-140.

National Oceanic and Atmospheric Administration (NOAA). 2018. International agreements concerning living marine resources of interest to NOAA fisheries. National Marine Fisheries Service, Silver Spring, Maryland, USA. [online] URL: https://www. fisheries.noaa.gov/resource/document/2018-noaa-fisheries-internationalagreements-book

Noone, K. J., U. R. Sumaila, and R. J. Diaz. 2013. Managing ocean environments in a changing climate: sustainability and economic perspectives. Elsevier, Amsterdam, The Netherlands.

Oremus, K. L., J. Bone, C. Costello, J. G. Molinos, A. Lee, T. Mangin, and J. Salzman. 2020. Governance challenges for tropical nations losing fish species due to climate change. Nature Sustainability 3:277-280. https://doi.org/10.1038/s41893-020-0476y

Palacios-Abrantes, J., U. R. Sumaila, and W. W. L. Cheung. 2020. Challenges to transboundary fisheries management in North America under climate change. Ecology and Society 25(4):41. https://doi.org/10.5751/ES-11743-250441

Pinsky, M. L., B. Worm, M. J. Fogarty, J. L. Sarmiento, and S. A. Levin. 2013. Marine taxa track local climate velocities. Science 341(6151):1239-1242. https://doi.org/10.1126/science.1239352

Pinsky, M. L., and M. Fogarty. 2012. Lagged social-ecological responses to climate and range shifts in fisheries. Climatic Change 115(3-4):883-891. https://doi.org/10.1007/s10584-012-0599-X

Pinsky, M. L., G. Reygondeau, R. Caddell, J. Palacios-Abrantes, J. Spijkers, and W. W. L. Cheung. 2018. Preparing ocean governance for species on the move. Science 360(6394):1189-1191. https://doi.org/10.1126/science.aat2360

Pörtner, H. O., D. M. Karl, P. W. Boyd, W. W. L. Cheung, S. E. Lluch-Cota, Y. Nojiri, D. N. Schmidt, and P. O. Zavialov. 2014. Ocean systems. Pages 411-484 in C. B. Field, V. R. Barros, D. J. Dokken, K. J. Mach, M. D. Mastrandrea, T. E. Bilir, M. Chatterjee, K. L. Ebi, Y. O. Estrada, R. C. Genova, B. Girma, E. S. Kissel, A. N. Levy, S. MacCracken, P. R. Mastrandrea, and L. L. White, editors. Climate change 2014: impacts, adaptation and vulnerability. Part A: global and sectoral aspects. Contribution of Working Group II to the Fifth Assessment Report of the Intergovernmental Panel on Climate Change. Cambridge University Press, Cambridge. https://doi.org/10.1017/ CBO9781107415379.011

Soboil, M. L., and J. G. Sutinen. 2006. Empirical analysis and transboundary management for Georges Bank multispecies fishery. Canadian Journal of Fisheries and Aquatic Sciences 63 (4):903-916. https://doi.org/10.1139/f05-269 
Sumaila, U. R. 1995. Irreversible capital investment in a two-stage bimatrix fishery game model. Marine Resource Economics 10 (3):263-283. https://doi.org/10.1086/mre.10.3.42629591

Sumaila, U. R. 1997a. Cooperative and non-cooperative exploitation of the Arcto-Norwegian cod stock. Environmental and Resource Economics 10(2):147-165

Sumaila, U. R. 1997b. Strategic dynamic interaction: the case of Barents Sea fisheries. Marine Resource Economics 12(2):77-93. https://doi.org/10.1086/mre.12.2.42629187

Sumaila, U. R. 1997c. A review of game theoretic models of fishing. Working paper. Chr. Michelsen Institute, Bergen, Norway. [online] URL: https://www.cmi.no/publications/1178-a-reviewof-game-theoretic-models-of-fishing

Sumaila, U. R. 2013. Game theory and fisheries: essays on the tragedy of free for all fishing 1st edition. Routledge, Oxon, UK. https://doi.org/10.4324/9780203083765

Sumaila, U. R. 2019. Climate change: impact on marine ecosystems and world fisheries. Pages 218-222 in P. Ferranti, J. R. Anderson, and E. M. Berry, editors. Encyclopedia of food security and sustainability. Elsevier, Amsterdam, The Netherlands. https:// doi.org/10.1016/B978-0-08-100596-5.22009-X

Sumaila, U. R., A. D. Marsden, R. Watson, and D. Pauly. 2007. A global ex-vessel fish price database: construction and applications. Journal of Bioeconomics 9(1):39-51. https://doi. org/10.1007/s10818-007-9015-4

Sumaila, U. R., S. I. Steinshamn, D. Boyer, and M. D. Skogen. 2004. Namibia's fisheries: ecological, economic, and social aspects. Eburon, Utrecht, The Netherlands.

Swartz, W., U. R. Sumaila, and R. Watson. 2013. Global ex-vessel fish price database revisited: a new approach for estimating "missing" prices. Environmental and Resource Economics 56 (4):467-480. https://doi.org/10.1007/s10640-012-9611-1

Tai, T. C., T. Cashion, V. W. Y. Lam, W. Swartz, and U. R. Sumaila. 2017. Ex-vessel fish price database: disaggregating prices for lowpriced species from reduction fisheries. Frontiers in Marine Science 4(363):1-10. https://doi.org/10.3389/fmars.2017.00363

Transboundary Resources Assessment Committee (TRAC). 2016. Proceedings of the Transboundary Resources Assessment Committee for Eastern Georges Bank cod and haddock, and Georges Bank yellowtail flounder. Fisheries and Oceans Canada (DFO), Ottawa, Ontario, Canada, National Marine Fisheries Services (NOAA Fisheries), Woods Hole, Massachusetts, USA.

Zeller, D., M. L. D. Palomares, A. Tavakolie, M. Ang, D. Belhabib, W. W. L. Cheung, V. W. Y. Lam, E. Sy, G. Tsui, K. Zylich, and D. Pauly. 2016. Still catching attention: Sea Around $U_{s}$ reconstructed global catch data, their spatial expression and public accessibility. Marine Policy 70:145-152. https://doi.org/10.1016/j.marpol.2016.04.046 
Appendix 1. Results from the sensitivity analysis on economic variables.
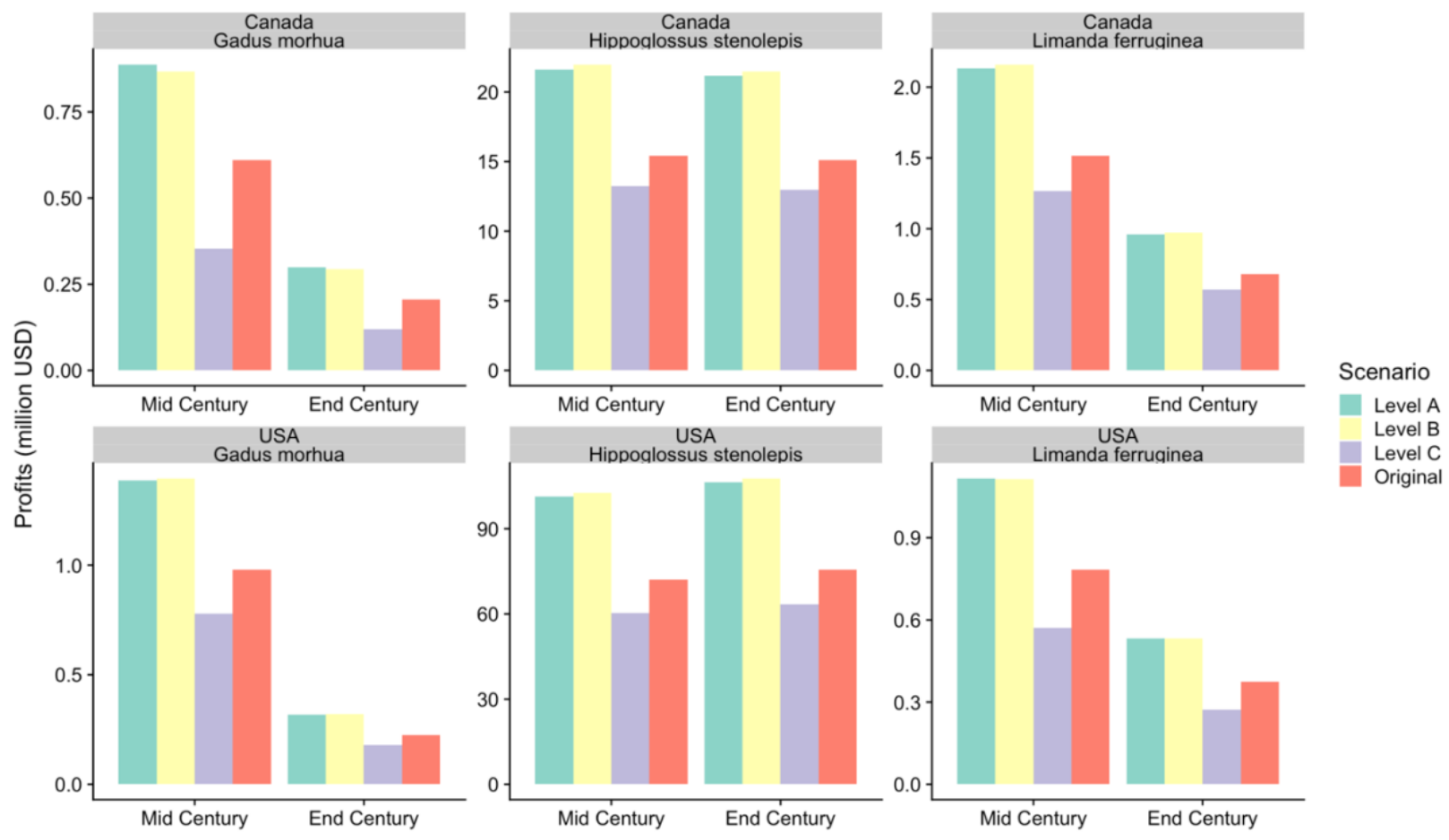

Fig. A1. Profits for mid and end of the 21st century under different future scenarios of price and cost. Each level represents the original value $\mathrm{x}$ random multiplayer (see Table A1). Category "Original" represents the values used in the present study.

Table A1. Values randomly selected for each future scenario used in the sensitivity analysis

\begin{tabular}{llll}
\hline Variable & Level A & Level B & Level C \\
\hline Price & $1.362173(36 \%)$ & $1.425854(43 \%)$ & $1.061325(6 \%)$ \\
Cost & $1.311245(31 \%)$ & $1.427684(43 \%)$ & $1.323787(32 \%)$ \\
\hline \hline
\end{tabular}

